УДК 811.511.142

DOI: 10.36624/2220-4156-2018-8-1-86-97

\title{
Bilingualism and text edition
}

\author{
M. Sipos \\ Research Institute for Linguistics, Hungarian Academy of Sciences, Budapest, Hungary, \\ sipos.maria@nytud.mta.hu
}

\begin{abstract}
Introduction: the present paper focuses on the practice of editing texts before the formation of the study of bilingualism, by means of a representative example of a Šerkaly Khanty chrestomathy.

Objective: the theory and practice of every field of science are continuously developing and refining, due to, among other things, the appearance of new research areas that may enrich the methodology of the related disciplines with many useful aspects and considerations.

Research materials: the present case study is intended to illustrate that, accordingly, in Uralic studies, the principles of text edition before the rise of documentary linguistics and investigations in bilingualism were considerably different from today's expectations.

Results and novelty of the research: the paper focuses on the syntactic differences between two versions of one and the same text, which was produced by a bilingual speaker. The syntactically modified excerpts were published by Wolfgang Steinitz himself in 1950, in his Šerkaly Khanty chrestomathy, whereas the whole text became available in a posthumous volume of Steinitz's heritage in 1989, unchanged. Khanty word order is traditionally considered verb final (SOV, SXV). By going through the modified clauses, it is shown that the proportion of non-verb-final sentences was radically decreased during the editing process, i.e. in the chrestomathy, numerous clauses were adjusted to the expected pattern by modifying its structure. Furthermore, the excerpts published in the chrestomathy were selected from sections exhibiting a relatively low number of SVO / SVX sentences. All this indicates that in the middle of the 20th century, i.e. before the formation of contact linguistics, the authenticity of a text that bears the consequences of Khanty-Russian bilingualism was not considered of primary importance.
\end{abstract}

Key words: Šerkaly Khanty, SOV word order, bilingualism, authenticity, text edition.

For sitation: Sipos M. Bilingualism and text edition // Vestnik ugrovedenia = Bulletin of Ugric studies. 2018; 8(1): 86-97.

\section{Двуязычие и издание текстов}

\author{
М. Шипош \\ Финно-угорский и историко-лингвистический отдел, Институт языкознания, \\ Венгерская Академия Наук, г. Будапешт, Венгрия, \\ sipos.maria@nytud.mta.hu
}

\section{АННОТАЦИЯ}

Введение: настоящая статья посвящена практике редактирования текстов до становления исследований двуязычия на репрезентативном примере иллюстрированной хрестоматии шеркалинского диалекта хантыйского языка.

Цель: теория и практика каждой области науки непрерывно развиваются и совершенствуются, в том числе за счет появления новых направлений исследований, которые могут обогатить методологию смежных дисциплин многими полезными ракурсами и взглядами.

Материалы исследования: настоящее тематическое исследование призвано проиллюстрировать, что принципы уралистики с точки зрения издания текстов до возникновения документальной лингвистики и исследований в области билингвизма существенно отличались от сегодняшних.

Результаты и научная новизна: в статье рассматриваются синтаксические различия между двумя версиями одного и того же текста, который был подготовлен двуязычным информатором. Синтаксически измененные выдержки были опубликованы самим Вольфгангом Штейницем в 1950 году в хрестоматии шеркальского диалекта хантыйского языка, тогда как полный неизменённый текст стал доступен в 1989 году, когда посмертно было издано наследие Штейница. Традиционно для хантыйского языка характерной является последняя позиция сказуемого в предложении (SOV, SXV). После изменений в процессе редактирования было установлено, что доля предложений со сказуемым на последней позиции была существенно уменьшена, т. е. в хрестоматии большая часть предложений была скорректирована в соот- 
ветствии с ожидаемым шаблоном порядка слов. Кроме того, выдержки, опубликованные в хрестоматии, были отобраны из разделов, содержащих относительно небольшое число предложений типа SVO / SVX. Все это свидетельствует о том, что в середине XX века, т. е. до формирования контактной лингвистики, аутентичность текста, несущего последствия русско-хантыйского билингвизма, не имела первостепенного значения.

Ключев ые слова: шеркальский диалект хантыйского языка, SOV/SXV порядок слов, двуязычие, аутентичность, редактирование.

Для циитирования: Шипош М. Двуязычие и издание текстов // Вестник угроведения. 2018. Т. 8. № 1. C. $86-97$.

\section{Introduction}

Authenticity, as well as establishing the principles of publishing linguistic materials have proved to be key elements in several fields of linguistics, among them historical linguistics. The most well-known principles concerning the edition of historical texts are those proposed by Lass, which have formed during the compilation of the Linguistic Atlas of Early Middle English $[38,22 ; 18,7-8]$. With respect to authenticity, Lass considers edited texts rather dangerous for the very reason scientists generally trust them. He does not mince his words: he is definitely against any emendation, modernization, alteration of any scribal word-division, delineation, or any attempt for reconstruction, not to mention any form of normalization $[38,21-22]$.

\section{Materials and methods}

Similarly, documentary linguistics has also elaborated the principles of its methodology, contributing to the knowledge of theoretical and practical considerations of the treatment and processing of linguistic data [e.g. 7].

Generally speaking, the appearance of any new subfield of linguistics is accompanied by the formation of new aspects in how to treat linguistic materials. That is, looking back through just a few decades, the norms of editing texts before the evolution of subfield-specific principles might seem unmethodical.

The present paper is a case study presenting the methodology of treating the linguistic material produced by a bilingual speaker in the 1930s. The language of the investigated texts is Khanty (Ob-Ugric, Uralic), more specifically its Šerkaly dialect, which was spoken in the middle region of the $\mathrm{Ob}$ River.

\section{Results}

The development of contact linguistics

Contact linguistics as a new field evolved in the course of the $20^{\text {th }}$ century. Interest in language contact issues has been present in linguistics since the end of the $19^{\text {th }}$ century, although some findings from the $17^{\text {th }}$ century are also mentioned in the literature $[41,6]$. In the first half of the $20^{\text {th }}$ century, two research trends affirmed this direction: first, the documentary fieldwork carried out among the indigenous peoples of the Americas $[38,31]$, second, on the languages of European immigrants in America [41, 8]. In the beginning, the attitude towards the results of bilingualism was not positive. For instance, Bloomfield classified native speakers according to their Menomini speech production, preferring those whose language competence was least influenced by their English knowledge [3, 90-91]. That is, while documenting endangered languages, bilingualism was considered a kind of deviation from the norm, in other words, it was thought to be an imperfect state $[38,31]$.

It became an independent research focus after the publication of Haugen's and Weinreich's views [7; 8; 40]. Still, contact linguistics was declared as a new research field only as late as $1979 .{ }^{1}$ The reasons for this slow development is partly the simultaneously growing interest in generative linguistics at the time, as well as certain fields of sociolinguistics $[13,1]$. The monograph on bilingualism written by Thomason and Kaufman [35] gave a considerable stimulus to the rise of this field. Today, research in bilingualism as well as in language contact have several subfields. Historical, sociolinguistic, cognitive psychological aspects are investigated at various levels, e.g. in phonology, syntax, as well as in pragmatics. Furthermore, areal linguistics and language typology also have points of contact with it [13, 2-3].

\section{Contact linguistics and Uralic studies}

During the 20th century, a great number of monographs were written in which the

${ }^{1}$ The term was introduced at the First World Congress on Language Contact and Conflict, held in Brussels in June 1979 [21, 287]. 
loanwords of Uralic languages borrowed from the neighbouring languages are discussed, classified along semantic aspects, linked to periods according to the actual time of borrowing etc. (concerning the Ob-Ugric languages cf. $[23 ; 36 ; 37 ; 16 ; 25$; $6 ; 27]$ etc. These investigations were primarily determined by etymological or lexicographic interests. Although it is a relatively young discipline, due to the sociolinguistic conditions the minor Uralic languages face, contact linguistics is becoming more and more significant in Uralic studies (e.g. [39; 19; 4; 26; 15; 5; 20] etc.).

On Wolfgang Steinitz and his speaker

The prominent folklorist and linguist Wolfgang Steinitz (1905-1967), who is chief-editor and author of the dialectal and etymological dictionary of Khanty [32], among other publications of great importance, studied Uralistics in Breslau and Berlin. Later, he worked at the University of Berlin but in 1933 he was fired because of his political views. Having left his country, he moved to the Soviet Union with his family. He worked as a professor of Finno-Ugric languages in Leningrad for years, and he had an opportunity to collect Khanty language material not only at the Institute of Northern Peoples but he also spent some months at the $\mathrm{Ob}$ River carrying out what we now call language documentation. Later he had conflicts with the authorities and his colleagues because of the state policies towards ethnic minorities, and moved to Sweden in 1938, where he lived until the end of World War II [22, 28-29].

He used various methods when collecting texts: he either simply wrote down what his speaker dictated to him, or the speaker's speech production was recorded on wax cylinders, and, occasionally, he also asked the Khanty speaker to put down his personal accounts or tales by his own hand. This method, which was much ahead of Steinitz's time, resulted in a significant linguistic material $[33,95]$. In addition, with this method, Steinitz collected texts that are, even if not representing spontaneous speech, much closer to everyday speech than any folklore genre.

Kirill Illarionovič Maremjanin (1907-?), with whom Steinitz tried various documentary methods, spoke the Šerkaly dialect of the Khanty language. After a difficult but eventful childhood, he left his region for distant towns, and finally he was sent to political training in Moscow, and Leningrad as well [33, 305-307]. Maremjanin and his family were in contact with Russians, he undoubtedly spoke Russian as a second language quite early. Later, his political career and success as a performer of various folk genres must have deepened this knowledge.

In sum, in the 1930s, Wolfgang Steinitz collected excellent linguistic material from a North Khanty speaker who apparently had a competent knowledge of Russian. However, when in the 1950s he published his chrestomathy of Šerkaly and Synya dialects, specific investigations in contact linguistics or bilingualism were not characteristic of Uralic studies. ${ }^{2}$ In the present case study, I aim to present the methods of publishing texts of a bilingual speaker in this period.

\section{Word order in the text editions}

The language of the chrestomathy

A chrestomathy is a didactic genre of compiled texts, its use is characteristic also of teaching Uralic languages. It contains excerpts from various folklore and literary genres preceded by a brief research history and a grammar sketch, and followed by a practical word list and bibliography. The structure of Steinitz's chrestomathy (Steinitz 1950) hardly differs from the pattern described above.

Although Éva Schmidt's Šerkaly grammar [29] is definitely based on these texts, yet she criticizes the language of this chrestomathy: "Compared to the expressive and fluent language of ÉONyT, ${ }^{3}$ the texts of the Ostyak Chrestomathy feel almost primitive" $[28,29] .{ }^{4}$ Naturally, Steinitz must have aimed to gather easily comprehensible texts for the didactic purposes of the chrestomathy, and, from a philological point of view, the simplicity of the texts have several reasons. First, there are folktales in Steinitz's collections that were recorded several times, using different methods. From these versions, Steinitz chose the folklore texts performed in a quite simple language. They are the versions dictated by Maremjanin in the first period, i.e. when the speaker was afraid that the fieldworker would not understand complicated phrases or long sentences, and tried to simplify them $[31,6 ; 33,223]$. Second, what concerns Maremjanin's personal accounts, i.e. the

\footnotetext{
${ }^{2}$ This chrestomathy became the most frequently used source of the Šerkaly dialect for decades, cf. the examples in the chapter on Khanty syntax in [14, $88-106]$.

${ }^{3}$ It is a text collection in the Obdorsk dialect [24].

${ }^{4}$ «Az ÉONyT kifejező, könnyed nyelve mellett szinte primitívnek hatnak az OChr serkáli szövegei» [28, 29].
} 
non-folklore part of the chrestomathy's material, the speaker cannot have had much practice at penning his own thoughts in Khanty, thus his sentences are often short, and might feel awkward. However, these memoires are still of great importance for the previously given reasons.

\section{Comparison of the text editions}

Fragments of these stories were published in the chrestomathy in question [33, 81-87], then, after Steinitz's death the whole material became available [34]. This latter one served as a base for syntactic investigations concerning the word order of relatively early texts [9]. Similarly to the Uralic protolanguage, Khanty is considered to have a basically verb final (SOV, SXV) word order $[10,81][2,56 ; 14,88 ; 1,380] . .^{5}$ In the North Khanty (Šerkaly) material, the proportion of SVX clauses was $12.5 \%$, which can be explained with the influence of the Russian language because postverbal focus is not characteristic in the Khanty language [9]. ${ }^{6}$

It was this research that turned the attention to the syntactic differences between the excerpts and the whole material. Namely, in the chrestomathy [31], the proportion of the clauses exhibiting SVX word order is lower than in the whole text [34]. This proved to be the result of several operations, which are presented one by one below. As is shown in Table 1, Steinitz used only a small part of the texts.

Table 1

Maremjanin's texts in Steinitz 1989 and Steinitz 1950

\begin{tabular}{|c|c|c|c|}
\hline \multicolumn{3}{|c|}{ Steinitz 1989} & Steinitz 1950 \\
\hline page & title & $\begin{array}{l}\text { number of } \\
\text { clauses }\end{array}$ & $\begin{array}{c}\text { number of } \\
\text { clauses }\end{array}$ \\
\hline $133-148$ & Ich schreibe über mein Leben & 324 & 53 \\
\hline $153-157$ & Ich arbeitete beim Kaufmann & 94 & 0 \\
\hline $159-160$ & Ich ging jagen & 55 & 15 \\
\hline $162-162$ & Ich feierte Bärenfeste & 15 & 12 \\
\hline $163-164$ & Ich ging mit meinem Großvater Fallen nachsehen & 25 & 0 \\
\hline $165-166$ & Ich kämpfte mit den Schamanen und mit den Kulaken & 41 & 0 \\
\hline $167-168$ & Ich befahl den Kindern $(\ldots)$ & 18 & 0 \\
\hline $168-171$ & Ich nahm mir eine Frau & 90 & 0 \\
\hline $173-176$ & Wie ich Fische fangen lernte & 99 & 0 \\
\hline 178-179 & Ich arbeitete für Lohn bei dem kleinen Gavril & 31 & 29 \\
\hline 179-182 & Wie ich zuerst Eichhörnchen jagen lernte & 72 & 39 \\
\hline $183-184$ & Ich starb fast bei der Arbeit beim Kaufmann & 22 & 22 \\
\hline $185-185$ & Mein Großvater gezählt & 13 & 0 \\
\hline 186-187 & Ich will das Leben meines Großvaters erzählen & 24 & 0 \\
\hline 188-189 & Ich erzähle das Leben meines Vaters & 22 & 21 \\
\hline $190-191$ & Ich erzähle das Leben meiner Mutters & 26 & 16 \\
\hline 192-192 & Wo ich singen und erzählen lernte & 17 & 0 \\
\hline 193-197 & Bärenjagd & 116 & 115 \\
\hline
\end{tabular}

Ranging from zero to $19.3 \%$ (for figures, see the footnote ${ }^{7}$ ), the proportions of the SVX clauses within the individual parts of Maremjanin's material are quite diverse. That is, Steinitz could have had the opportunity to select on the basis of the syntactic properties of the chapters. However, it seems not to have been his primary consideration.

\footnotetext{
${ }^{5}$ Evidently, both Honti and Abondolo give more specified overviews of the Khanty word order.

${ }^{6}$ This is an extremely simplified summary of the paper's conclusions; in the Eastern Khanty dialect, the SVX word order has different motivations, namely, backgrounding. However, the influence of Russian might explain the SVX sentences in the North Khanty material, i.e. in Maremjanin's non-folklore texts.

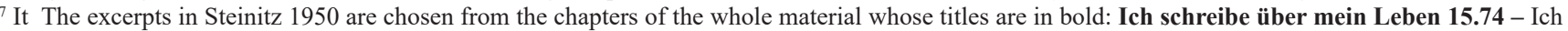
arbeitete beim Kaufmann 17.02 - Ich ging jagen 12.72 - Ich feierte Bärenfeste 6.66 - Ich ging mit meinem Großvater Fallen nachsehen 12 - Ich kämpfte mit den Schamanen und mit den Kulaken 7.31 - Ich befahl den Kindern, sich als Komsomolzen einzuschreiben 0 - Ich nahm mir eine Frau 7.77 - Wie ich Fische fangen lernte 8.08 - Ich arbeitete für Lohn bei dem kleinen Gavril 6.45 - Wie ich zuerst Eichhörnchen jagen lernte 9.72 - Ich starb fast bei der Arbeit beim Kaufmann 4.54 - Mein Großvater gezählt 7.69 - Ich will das Leben meines Großvaters erzählen 12.5 - Ich erzähle das Leben meines Vaters 4.54 - Ich erzähle das Leben meiner Mutters 19.23 - Wo ich singen und erzählen lernte 17.64 - Bärenjagd 8.6.
} 
Editorial corrections in the chrestomathy

Deletion of the SVX clausesfrom the excerpts

In several excerpts, SVX clauses are simply deleted from the published version. E.g. in the chrestomathy, from the chapter about Maremjanin's mother, four sentences of remarkable societal details are left out, among which the second and the fourth ones contain postverbal adverbials (1a-d): ${ }^{8}$

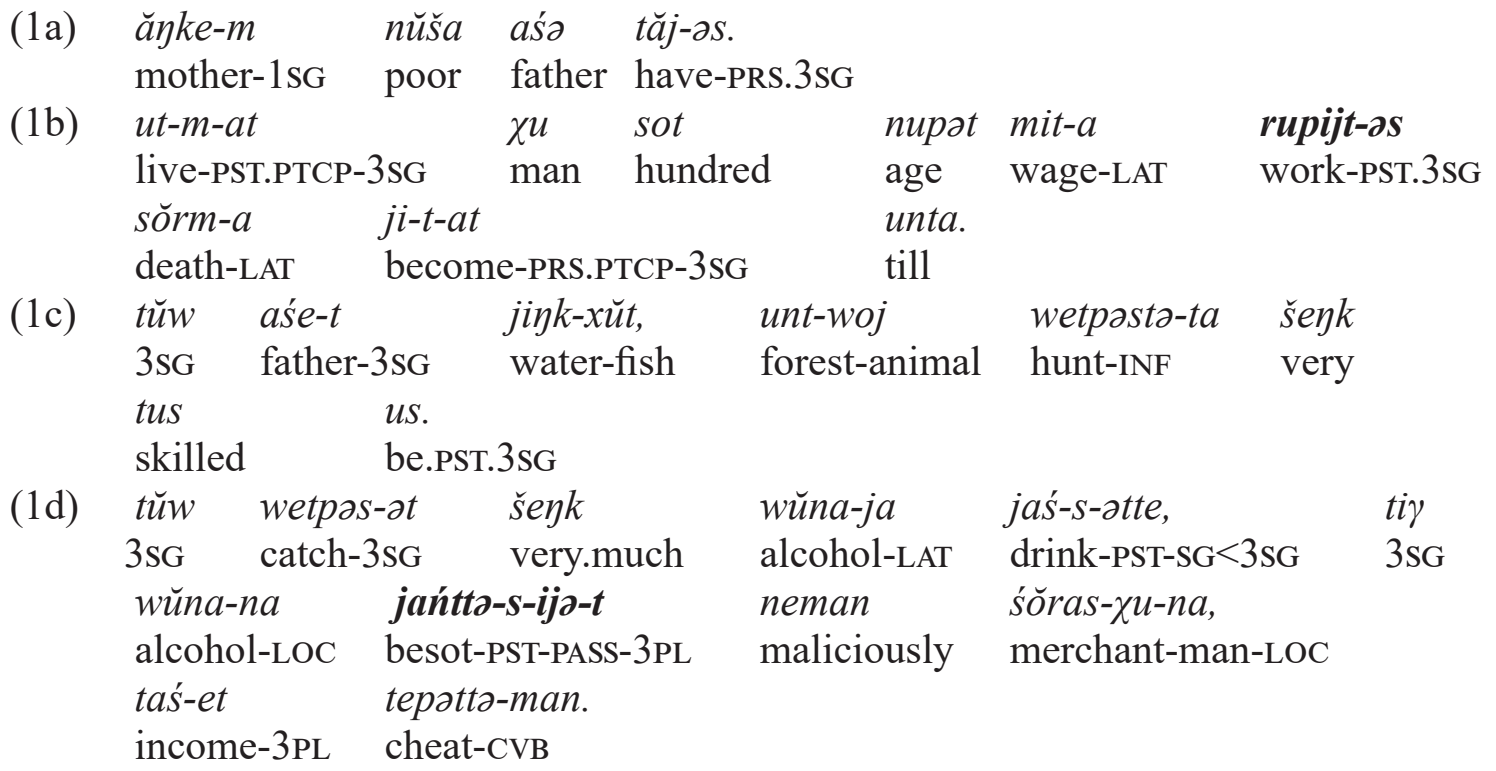

'My mother's father was poor. In his whole life, until his death, he worked as a wageworker. His father was a very skilled hunter and fisherman. However, he mostly drank all his wages, they were maliciously got drunk and conned out of their money by the merchant.' $[34,190]$ vs $[31,81]$.

The motivation to delete the above sentences can have been merely editorial as they are not closely related to the actual part about Maremjanin's mother.

In the following example, deletion is accompanied by a restructuring of the sentences. The first sentence, containing a postverbal purpose infinitive, was left out (2a), and only its temporal adverbial ('one night') was transposed to the next sentence (2b), cf. (3):

(2a) ij at măn-s-əm tow pum pŏn-ta. one night go-PST-1SG horse grass put-INF

(2b)tow xot tipaja tăy-s-om, tow-ət-a tow pum mă-ta pit-s-əm. horse house into enter-PST-1SG horse-PL-LAT horse grass give-INF start-PST-1SG $[34,178]$.

'One night I went to put hay (into the feeder). I entered the stable and started to give hay to the horses.'

(3) $i j$ at tow xot tipaja tăy-s-om, tow-ət-a tow pum one night horse house into enter-PST-1SG_ horse-PL-LAT horse grass mă-ta pit-s-əm. give-INF start-PST-1SG

$[31,82]$.

\footnotetext{
${ }^{8}$ In the contrasted sentence pairs, predicates are always indicated by bold characters.
} 
'One night I entered the stable and started to give hay to the horses.'

Transforming postverbal parts of the sentence into an afterthought

(4) 'tat' tiy-əm battle be.born-PST.PTCP time-LOC kawar xóśna.

Gavril at $[34,134]$.
There are examples of transforming SVX sentences into an SXV with an afterthought. In the chrestomathy, sentence (4) below is published with a comma after the predicate $(31,83)$ :

xăta-pan-kurt-na rupojt-s-əm aj xăta-pan-kurt-LOC work-PST-1SG little
'When the fights began, I worked at Khatapankurt, at Little Gavril.'

\section{Cutting postverbal parts of sentence}

In some cases, the number of postverbal sentence parts is reduced even if it does not result in an SXV word order (5a-b):

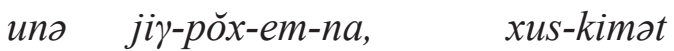

big father-son-1sG-LOC twenty-second

\begin{tabular}{lll} 
first forest-LAT & \multicolumn{2}{l}{ take-PST-PASS-1SG } \\
tătə-na, & unt pelək juš- $a$. \\
winter-LOC & forest & side path-LAT
\end{tabular}

$[34,179]$.

'I was first taken to hunt by my brother, in (19)22, to the path at the forest side'.
(5b) otəクna
$x \breve{a r}-a$
tu-s-əj-əm
unว jiү-pŏx-em-na.
first
forest-LAT
take-PST-PASS-1SG
big father-son-1sG-LOC
$[31,84]$.

'I was first taken to hunt by my brother.'

\section{Change in word order}

The most frequent syntactic modification in [31] is transforming SVX clauses into SVX ones. It is generally carried out by exchanging words or phrases within the sentence (6a-b)-(7a-b)-(8ab)-(9a-b). Word order is modified even in such clauses that also contain an afterthought (10a-b). In other cases, both the word order is transformed and the afterthought is cut as well (11a-b). Sometimes an afterthought is simply shifted to preverbal position (12a-b):

$\begin{array}{rlllll}\text { (6a) woš } & \text { ewat } & \text { t'eśatnik } & \text { tow } & \text { kăš-ta } & \text { jŏ } \chi \text { t-os } \\ \text { town } & \text { from } & \text { commander } & \text { horse } & \text { look.for-INF } & \text { arrive-PST.3sG }\end{array}$ $[34,134]$.

(6b) woš ewat t'eśatnik jŏ $\chi$ t-os, tow kăš-ta. town from commander arrive-PST.3SG horse look.for-INF $[31,83]$.

'There came a commander from the town in order to look for horses.'

(7a) ma tow-yotam-na 1SG horse-1SG. DU-LOC [34, 135].

(7b) ma tow-yatam-na 1sG horse-1sG.DU-LOC $[31,83]$.

'With the two horses, I left for the town.'

$$
\begin{array}{ll}
\text { măn-s-əm } & \text { woš- } a . \\
\text { go-PST-1SG } & \text { town-LAT }
\end{array}
$$

$$
\begin{array}{ll}
\text { woš- } a & \text { măn-s-əm. } \\
\text { town-LAT } & \text { go-PST-1SG }
\end{array}
$$

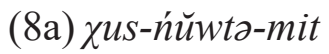
tătว-na ma

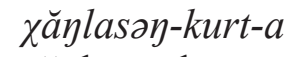
jă $\chi-s-a m$
wetpasta-ta. twenty-eight-ORD winter-LOC $1 \mathrm{SG}$

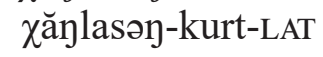




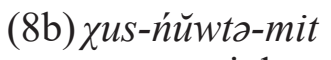
twenty-eight-ORD tătว-na

winter-LOC

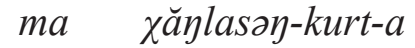

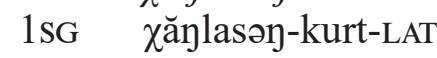

wetpastว-ta

hunt-INF jă $\chi-s-ə m$.

go-PST-1SG

$[31,85]$.

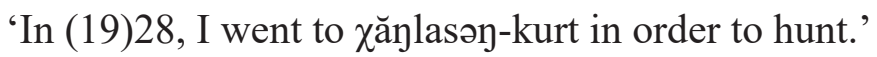

(9a) śeman

Simon

l̆op-ot ma petay-em...

$[34,194]$.

(9b) śeman

ma petay-em löp-ot...

Simon

$1 \mathrm{SG}$ to-1SG

tell-PRS.3SG

$[31,86]$.

'Simon told me, (...)'

(10a)

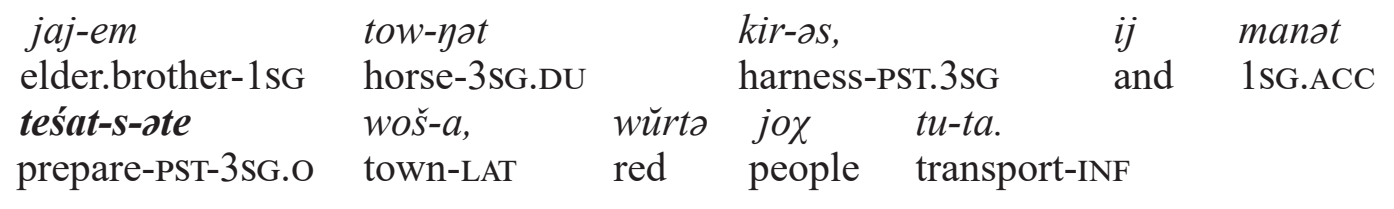

$[34,135]$.

(10b) jaj-em

elder.brother-1SG

teśat-s-ote,

tow-yot kir-as,

harness-PST.3sG

ij manat

woš- $a$

prepare-PST-3SG.o

horse-DU

jo $\quad t u-t a$.

and 1SG.ACC

town-LAT

red

people

transport-INF

$[31,83]$.

'My brother harnessed his two horses and got me ready to transport the communists to the town.'
tăj-os

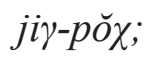
have-PST.3SG
$[34,188]$.
tăj-as;
father-son have-PST.3SG
$[31,81]$.

$j i \gamma-p \check{o} \chi-\partial t$

wasilij

gregorewits

maremjanin.

father-son

father-son-3SG

wasilij

gregorewits

maremjanin

'He had a brother; this brother was Vasily Grigorjevič Maremjanin.'

(11b) $j i \gamma-p \check{\chi} \chi$

'He had a brother.'

(12a) ojk

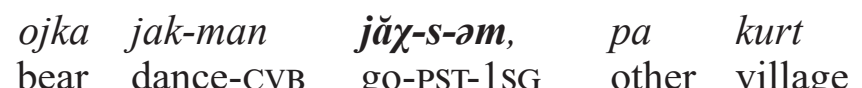

ewat pa kurt-a.

bear dance-CVB go-PST-1SG other village

from other village-LAT

$[34,194]$.

(12b) ojka

$$
\text { jak-man pa kurt ewat }
$$
dance-CvB other village from

pa kurt-a

other village-LAT

jă $\chi-s-\partial m$.

bear

$[31,87]$.

'I went from village to village keeping bear feast.' 
Selection within the chapters

With the exception of one chapter, the proportion of SVX clauses became lower in the chrestomathy. Besides the above modifications, it is also due to avoiding the details in the chapters that abound in SVX clauses.

Table 2

A summary of modifications ${ }^{9}$

\begin{tabular}{|c|c|c|c|c|c|}
\hline \multicolumn{3}{|c|}{ Steinitz 1989} & \multicolumn{3}{|c|}{ Steinitz 1950} \\
\hline title & $\begin{array}{c}\text { number of } \\
\text { clauses / SVX } \\
\text { clauses }\end{array}$ & $\%$ & $\begin{array}{c}\text { number of } \\
\text { clauses / } \\
\text { SVX clauses }\end{array}$ & $\%$ & modifications \\
\hline $\begin{array}{c}\text { Ich schreibe über mein } \\
\text { Leben }\end{array}$ & $324 / 51$ & 15.74 & $53 / 4$ & 7.54 & $\begin{array}{l}3 \text { changes in word order } \\
1 \mathrm{SVX} \rightarrow \text { afterthought }\end{array}$ \\
\hline Ich ging jagen & $55 / 7$ & 12.72 & $15 / 1$ & 6.66 & 1 change in word order \\
\hline Ich feierte Bärenfeste & $15 / 1$ & 6.66 & $12 / 0$ & $\mathbf{0}$ & 1 change in word order \\
\hline $\begin{array}{c}\text { Ich arbeitete für Lohn bei } \\
\text { dem kleinen Gavril }\end{array}$ & $31 / 2$ & 6.45 & $29 / 1$ & 3.44 & 1 deletion \\
\hline $\begin{array}{c}\text { Wie ich zuerst } \\
\text { Eichhörnchen jagen lernte }\end{array}$ & $72 / 7$ & 9.72 & $39 / 0$ & $\mathbf{0}$ & 1 deletion of afterthought \\
\hline $\begin{array}{l}\text { Ich starb fast bei der } \\
\text { Arbeit beim Kaufmann }\end{array}$ & $22 / 1$ & 4.54 & $22 / 1$ & 4.54 & 0 \\
\hline $\begin{array}{l}\text { Ich erzähle das Leben } \\
\text { meines Vaters }\end{array}$ & $22 / 1$ & 4.54 & $21 / 0$ & $\mathbf{0}$ & $\begin{array}{c}1 \text { change in word order } \\
1 \text { deletion }^{10}\end{array}$ \\
\hline $\begin{array}{l}\text { Ich erzähle das Leben } \\
\text { meiner Mutters }\end{array}$ & $26 / 5$ & 19.23 & $16 / 3$ & 18.75 & 2 deletions \\
\hline Bärenjagd & $116 / 10$ & 8.6 & $115 / 8$ & 6.95 & $\begin{array}{c}3 \text { changes in word order } \\
1 \text { deletion }\end{array}$ \\
\hline & & & & $5.32 \%$ & \\
\hline
\end{tabular}

As can be seen, the decrease in the SVX proportion in the chrestomathy cannotbe explained with the previously given modifications. For instance, in the case of the chapter "Wie ich zuerst Eichhörnchen jagen lernte" half of the text was included in the chrestomathy. In the excerpt, there are no SVX clauses, and only one clause with an afterthought was left out. In the whole text of the chapter, by contrast, there are 7 SVX clauses. Consequently, Steinitz chose a syntactically preferable detail of the chapter in question. The same holds for the chapter "Ich ging jagen".

As a result of the procedures presented above, the proportion of the SVX clauses was lowered to about $5.3 \%$, which amounts to less than half of the original $12.5 \%$.

This kind of treatment cannot have been unique before the formation of contact linguistics, and we have no reason to suppose that such methods were unknown in the research history of other languages. For instance, in relation to the Evenki language, Grenoble mentions that it is difficult to find reliable sources from the early times because in text editions, the language material was often corrected and polished $[8,102]$.

\section{Discussion and conclusion}

In the 1930s, important language material was collected by Wolfgang Steinitz from a Šerkaly speaker. Among these texts, there are non-folklore parts, especially personal accounts that exhibit various characteristic phenomena of bilingual speech production. However, it is only some parts of this valuable material that were published by Steinitz himself, and the collection as a whole became available decades later.

\footnotetext{
${ }^{9}$ As in the above table the data of the the chapters and sections not published in the chrestomathy are not shown, the proportion of the SVX clauses is not $12.5 \%$.

${ }^{10}$ In the same sentence, see (11a-b).
} 
Having compared the syntax of the two versions, it can be stated that Steinitz aimed to transmit a more traditional syntactic character of the texts, that is, he alleviated the number of SVX clauses using different methods. Namely, he avoided the details rich in postverbal parts of sentences, corrected the word order, cut the postverbal parts of sentences, deleted whole sentences etc.

The fact that from among the folktale variants Steinitz selected the one with the simplest style can be explained with the didactic objectives of chrestomathies. The altering of the syntactic character of the text cannot. The reason for this procedure must be in connection with the history of researching bilingualism. At Steinitz's time the consequences of bilingualism were not considered natural phenomena, with the exception of loanwords. Similarly, the texts bearing these features were not found valuable either. It cannot be excluded that similar editorial (pre)conceptions were present during the editing process of further 20th century Khanty materials.

$\quad$ Abbreviations
1 - first person,
2 - second person,
3 - third person,
ACC - accusative,
CVB - converb,
DU - dual,
INF - infinitive,
LAT - lative,
LOC - locative,
O - objective conjugation,
PASS - passive,
PL - plural,
PRS - present,
PST - past,
PTCP - participle,
SG - singular.

\section{References}

1. Abondolo D. Khanty. In: Abondolo Daniel (ed), The Uralic languages. London - New York: Routledge, 1998. pp. 358-386 (In English)

2. Bereczki G. A magyar nyelv finnugor alapjai [The Finno-Ugric bases of Hungarian]. Budapest: Universitas, 1996. 132 p. (In Hungarian)

3. Bloomfield L. Literate and illiterate Speech. In: Hockett, Charles, F. (ed), A Leonard Bloomfield anthology. Chicago: University of Chicago Press, 1970. pp. 84-94. (In English)

4. Chelliah S.L., de Reuse W.J. Handbook of descriptive linguistic fieldwork. Dordrecht, Heidelberg, London, New York: Springer, 2011. 492 p. (In English)

5. Csepregi M., Gugán K. Orosz hatás az osztják aspektus- és akcióminőség-rendszerre [Russian influence in Ostyak aspect and aktionsart]. In: É. Kiss, Katalin and Hegedüs, Attila (eds), Nyelvelmélet és kontaktológia [Linguistic theory and contact linguistics]. Piliscsaba: Pázmány Péter Katolikus Egyetem, 2010. pp. 149-168. (In Hungarian)

6. Potanina O., Filchenko A. Russian contact-induced innovations in Eastern Khanty. Tomsk Journal $L I N G \&$ ANTHRO, 2 (12), 2016. pp. 29-39. (In Russian)

7. Futaky I. Tungusische Lehnwörter im Ostjakischen. Wiesbaden: Veröffentlichungen der Societas UraloAltaica. Band 10. 1975. (In German)

8. Grenoble L., Furbee N.L. (eds). Language documentation: Practice and values. Amsterdam Philadelphia: John Benjamins, 2010. 340 p. (In English)

9. Grenoble L.A. Areal typology and syntactic change. Вестник ТГПУ (TSPU Bulletin) 2012/1, 2012. pp. 101-104. (In English)

10. Gugán K., Sipos M. (in press). Ige mögötti mondatrészek régi hanti szövegekben [Postverbal syntactic constituents in Old Khanty texts]. (In Hungarian)

11. Hajdú P. Bevezetés az uráli nyelvtudományba [Introduction to Uralic linguistics]. Budapest: Tankönyvkiadó, 1966. 179 p. (In Hungarian)

12. Haugen E. The analysis of linguistic borrowing. Language, 26 (2), 1950. pp. 211-231. (In English)

13. Haugen E. The Norwegian language in America: A study in bilingual behavior. Philadelphia: University of Pennsylvania Press, 1953. 695 p. (In English)

14. Hickey R. (ed). The handbook of language contact. Oxford: Wiley-Blackwell, 2010. 888 p. (In English)

15. Honti L. Chrestomathia ostiacica. Budapest: Tankönyvkiadó, 1984. 285 p. (In Hungarian)

16. Kálmán B. Die russischen Lehnwörter im Wogulischen. Budapest: Akadémiai Kiadó, 1961. 327 p. (In German)

17. Kaysina I. The adoption of Russian conjunctions in Udmurt. Journal of Estonian and Finno-Ugric Linguistics 4 (2), 2013. pp. 131-144. (In English) 
18. LAEME-Introduction = Laing M., Lass R. A linguistic atlas of Early Middle English: An introduction. http://user.keio.ac.jp/ rhotta/hellog/etc/laeme_manual/Introchap3.pdf (accessed: 2017 Sept). (In English)

19. Lass R. Ut custodiant litteras: Editons, corpora and witnesshood. In: Dossena, M. and Lass, Roger, (eds). Methods and data in English historical dialectology. Bern: Peter Lang, 2004. 21-48. (In English)

20. Leinonen M. Influence of Russian on the syntax of Komi. Finnisch-Ugrische Forschungen 57, 2002. 195-358. (In English)

21. Mus N. Orosz-tundrai nyenyec nyelvi kontaktus: A tundrai nyenyec lokatív szerkezetekről [Russian and Tundra Nenets in contact: On Tundra Nenec locative constructions]. In: É. Kiss, Katalin, Hegedüs, Attila and Pintér, Lilla (eds), Nyelvelmélet és diakrónia 3 [Linguistic theory and diachrony]. Budapest-Piliscsaba: Pázmány Péter Katolikus Egyetem, 2016. 111-125. (In Hungarian)

22. Nelde P.H. Language conflict. In: Coulmas, Florian (ed) The handbook of sociolinguistics. Oxford: Blackwell, 1997. 285-300. (In English)

23. Noack K., Krause M. Ethnography as a unified anthropological science in the German Democratic Republic. In: Hann, Chris, Sárkány, Mihály and Skalnik, Peter (eds), Studying peoples in the people 's democracies: Socialist era anthropology in East Central Europe. Münster: LIT Verlag, 2005. 25-55. (In English)

24. Paasonen H. Über die türkischen Lehnwörter im Ostjakischen. Finnisch-Ugrische Forschungen 2, 1902. 81-137. (In German)

25. Pápay J. Északi osztják nyelvtanulmányok [Northern Ostyak linguistic studies]. Finnugor Füzetek 15. Budapest, 1910. 69 p. (In Hungarian)

26. Rédei K. Die syrjänische Lehnwörter im Wogulischen, The Hague: Mouton, 1970. 195 p. (In German)

27. Riessler M. Saami-Russian-Komi contacts in the Kola Peninsula. In: Blokland, Rogier. and Riessler, Michael. (eds), Language contact in times of globalization. Studies in Slavic and General Linguistics 38, 2011. 5-26. (In English)

28. Schiefer L. Russische Lehnwörter im Vach-Ostjakischen. Finnisch-Ugrische Mitteilungen 6, 1982. $163-$ 171. (In German)

29. Schmidt É. A nyelvfejlődés és nyelvújítás tükröződése a közép-obi és a kazimi osztják irodalmi nyelvben [Language development and signs of language renewal in the literary Ostyak of the Middle Ob region and of Kazim]. In: Sipos, Mária (ed), Nyelv, nyelvjárás, írásbeliség, irodalom. Schmidt Éva szakdolgozata és versfordításai. Schmidt Éva Könyvtár 2. MTA Nyelvtudományi Intézet, Budapest, 2006. 11-111. (In Hungarian)

30. Schmidt É. Északi osztják nyelvtani jegyzet (serkáli nyelvjárás) [Northern Ostyak grammatical notes (Serkaly dialect). In: Fejes, László (ed), Serkáli osztják chrestomathia [Serkaly Ostyak chrestomathia]. Schmidt Éva Könyvtár 3. Budapest: MTA Nyelvtudományi Intézet, 2008. 13-76. (In Hungarian)

31. Steinitz W. Ostjakische Grammatik und Chrestomathie. Leipzig: Otto Harrasowitz, 1950. 169 p. (In German)

32. Steinitz W. Dialektologisches und etymologisches Wörterbuch der ostjakischen Sprache. Berlin: Akademie Verlag, 1966-1988. 2023 p. (In German)

33. Steinitz W. Ostjakologische Arbeiten, Band 2. Ostjakische Volksdichtung und Erzählungen aus zwei Dialekten. Budapest: Akadémiai Kiadó, 1976. 320 p. (In German)

34. Steinitz W. Ostjakologische Arbeiten, Band 3. Texte aus dem Nachlass. Budapest: Akadémiai Kiadó, 1989. 641 p. (In German)

35. Thomason S.G., Kaufman T. Language contact, creolization, and genetic linguistics. Berkeley: University of California Press, 1988. 428 p. (In English)

36. Toivonen Yr.H. Türkische Lehnwörter im Ostjakischen. Journal de la Société Finno-Ougrienne 52/6, 1943-1944. 1-20. (In German)

37. Toivonen Yr.H. Über die syrjänischer Lehnwörter im Ostjakischen. Finnisch-Ugrische Forschungen 32, 1956. 1-169. (In German)

38. Tsunoda T. Language endangerment and language revitalization. Berlin - New York: Mouton de Gruyter, 2004. 307 p. (In English)

39. Várnai Z. A nganaszan nyelv orosz jövevényszavainak vizsgálata fonológiai automatával [An analysis of Russian loanwords in Nganasan using a phonological automaton]. Nyelvtudományi Közlemények 96. 1999. 170-193. (In Hungarian)

40. Weinreich U. Languages in contact: Findings and problems. New York: Linguistic Circle, 1953. 160 p. (In English)

41. Winford D. An introduction to contact linguistics. Oxford: Wiley-Blackwell, 2002. 434 p. (In English) 


\section{Список источников и литературы}

1. Abondolo D. Khanty // Abondolo Daniel (ed), The Uralic languages. London - New York: Routledge, 1998. pp. 358-386.

2. Bereczki G. A magyar nyelv finnugor alapjai. Budapest: Universitas, 1996. 132 p.

3. Bloomfield L. Literate and illiterate Speech // Hockett, Charles F. (ed), A Leonard Bloomfield anthology. Chicago: University of Chicago Press, 1970. pp. 84-94.

4. Chelliah S.L., de Reuse W.J. Handbook of descriptive linguistic fieldwork. Dordrecht, Heidelberg, London, New York: Springer, 2011. 492 p.

5. Csepregi M., Gugán K. Orosz hatás az osztják aspektus- és akcióminőség-rendszerre // É. Kiss Katalin, Hegedủs Attila (eds) Nyelvelmélet és kontaktológia. Piliscsaba: Pázmány Péter Katolikus Egyetem, 2010. pp. $149-168$.

6. Potanina O., Filchenko A. Russian contact-induced innovations in Eastern Khanty // Томский журнал лингвистических и антропологических исследований. 2016. № 2 (12). С. 29-39.

7. Futaky I. Tungusische Lehnwörter im Ostjakischen. Wiesbaden: Veröffentlichungen der Societas UraloAltaica. Band 10. 1975.

8. Grenoble L., Furbee N.L. (eds). Language documentation: Practice and values. Amsterdam - Philadelphia: John Benjamins, 2010. 340 p.

9. Grenoble L.A. Areal typology and syntactic change // Вестник ТГПУ. 2012. No 1. Pp. 101-104.

10. Gugán K., Sipos M. (in press). Ige mögötti mondatrészek régi hanti szövegekben.

11. Hajdú P. Bevezetés az uráli nyelvtudományb. Budapest: Tankönyvkiadó, 1966. 179 p.

12. Haugen E. The analysis of linguistic borrowing // Language. 1950. № 26 (2). Pp. 211-231.

13. Haugen E. The Norwegian language in America: A study in bilingual behavior. Philadelphia: University of Pennsylvania Press, 1953. 695 p.

14. Hickey R. (ed). The handbook of language contact. Oxford: Wiley-Blackwell, 2010. 888 p.

15. Honti L. Chrestomathia ostiacica. Budapest: Tankönyvkiadó, 1984. 285 p.

16. Kálmán B. Die russischen Lehnwörter im Wogulischen. Budapest: Akadémiai Kiadó, 1961. 327 p.

17. Kaysina I. The adoption of Russian conjunctions in Udmurt // Journal of Estonian and Finno-Ugric Linguistics. 2013. № 4 (2). Pp. 131-144.

18. LAEME-Introduction = Laing M., Lass R. A linguistic atlas of Early Middle English: An introduction. URL: http://user.keio.ac.jp/ rhotta/hellog/etc/laeme_manual/Introchap3.pdf (дата обращения: сентябрь 2017).

19. Lass R. Ut custodiant litteras: Editons, corpora and witnesshood// Dossena M., Lass R. (eds). Methods and data in English historical dialectology. Bern: Peter Lang, 2004. 21-48.

20. Leinonen M. Influence of Russian on the syntax of Komi // Finnisch-Ugrische Forschungen. 2002. № 57. Pp. 195-358.

21. Mus N. Orosz-tundrai nyenyec nyelvi kontaktus: A tundrai nyenyec lokatív szerkezetekről // Nyelvelmélet és diakrónia 3 / É. Kiss Katalin, Hegedüs Attila, Pintér Lilla (eds)/ Budapest-Piliscsaba: Pázmány Péter Katolikus Egyetem, 2016. 109-123.

22. Nelde P.H. Language conflict // Coulmas F. (ed) The handbook of sociolinguistics. Oxford: Blackwell, 1997. 285-300.

23. Noack K., Krause M. Ethnography as a unified anthropological science in the German Democratic Republic // Studying peoples in the people's democracies: Socialist era anthropology in East Central Europe / Hann C., Sárkány M., Skalnik P. (eds). Münster: LIT Verlag, 2005. 25-55.

24. Paasonen H. Über die türkischen Lehnwörter im Ostjakischen // Finnisch-Ugrische Forschungen. 1902. 2. Pp. 81-137.

25. Pápay J. Északi osztják nyelvtanulmányok. Finnugor Füzetek 15. Budapest, 1910. 69 p.

26. Rédei K. Die syrjänische Lehnwörter im Wogulischen. Hague: Mouton, 1970. 195 p.

27. Riessler M. Saami-Russian-Komi contacts in the Kola Peninsula // Blokland, Rogier. and Riessler, Michael. (eds) Language contact in times of globalization. Studies in Slavic and General Linguistics. 2011. 38. Pp. 5-26.

28. Schiefer L. Russische Lehnwörter im Vach-Ostjakischen // Finnisch-Ugrische Mitteilungen.1982. 6. Pp. $163-171$.

29. Schmidt É. A nyelvfejlődés és nyelvújitás tükröződése a közép-obi és a kazimi osztják irodalmi nyelvben // Sipos M. (ed) Nyelv, nyelvjárás, írásbeliség, irodalom. Schmidt Éva szakdolgozata és versfordításai. Schmidt Éva Könyvtár 2. Budapest: MTA Nyelvtudományi Intézet, 2006. Pp. 11-111. 
30. Schmidt É. Északi osztják nyelvtani jegyzet (serkáli nyelvjárás) // Serkáli osztják chrestomathia. Schmidt Éva Könyvtár 3. Fejes László (ed). Budapest: MTA Nyelvtudományi Intézet, 2008. Pp. 13-76.

31. Steinitz W. Ostjakische Grammatik und Chrestomathie. Leipzig: Otto Harrasowitz, 1950. 169 p.

32. Steinitz W. Dialektologisches und etymologisches Wörterbuch der ostjakischen Sprache. Berlin: Akademie Verlag, 1966-1988. 2023 p.

33. Steinitz W. Ostjakologische Arbeiten. Band 2: Ostjakische Volksdichtung und Erzählungen aus zwei Dialekten. Budapest: Akadémiai Kiadó, 1976. 320 p.

34. Steinitz W. Ostjakologische Arbeiten. Band 3: Texte aus dem Nachlass. Budapest: Akadémiai Kiadó, 1989. $641 \mathrm{p}$.

35. Thomason S.G., Kaufman T. Language contact, creolization, and genetic linguistics. Berkeley: University of California Press, 1988. 428 p.

36. Toivonen Yr.H. Türkische Lehnwörter im Ostjakischen// Journal de la Société Finno-Ougrienne.1943-1944. 52/6. Pp. 1-20.

37. Toivonen Yr.H. Über die syrjänischer Lehnwörter im Ostjakischen // Finnisch-Ugrische Forschungen. 1956. 32. Pp. 1-169.

38. Tsunoda T. Language endangerment and language revitalization. Berlin - New York: Mouton de Gruyter, 2004. $307 \mathrm{p}$.

39. Várnai Z. Anganaszan nyelv oroszjövevényszavainak vizsgálata fonológiai automatával//Nyelvtudományi Közlemények. 1999. 96. Pp. 170-193.

40. Weinreich U. Languages in contact: Findings and problems. New York: Linguistic Circle, 1953. 160 p.

41. Winford D. An introduction to contact linguistics. Oxford: Wiley-Blackwell, 2002. 434 p.

\section{ABOUT THE AUTHOR:}

Sipos Maria, Senior Research Fellow, Head of Department, Department of Finno-Ugric Studies and Historical Linguistics, Research Institute for Linguistics, Hungarian Academy of Sciences (33 Benczúr Str., Budapest, Hungary-1068).

ORCID ID: 0000-0001-5269-7784

sipos.maria@nytud.mta.hu

\section{ИНФОРМАЦИЯ ОБ АВТОРЕ:}

Шипош Мария, научный сотрудник, заведующий отделом, Финно-угорский и историко-лингвистический отдел, Институт языкознания, Венгерская Академия Наук (1068, Венгрия, Будапешт, ул. Бенцура 33).

ORCID ID: 0000-0001-5269-7784

sipos.maria@nytud.mta.hu, 